\title{
Rainfall Monitoring to Support Temporal and Spatial Information of Debris Flow Initiation in Merapi Volcano
}

\author{
Ani Hairani ${ }^{1 *}$, Adam Pamudji Rahardjo ${ }^{2}$, Djoko Legono² ${ }^{2}$ Istiarto $^{2}$ \\ ${ }^{1}$ Civil Engineering Department, \\ Universitas Muhammadiyah Yogyakarta, Kasihan, Bantul, 55183, INDONESIA \\ ${ }^{2}$ Department of Civil and Environmental Engineering, \\ Universitas Gadjah Mada, Grafika Street, Kampus No. 2, Sleman, 55281, INDONESIA \\ *Corresponding Author
}

DOI: https://doi.org/10.30880/ijie.2021.13.03.016

Received 20 December 2020; Accepted 01 May 2021; Available online 06 June 2021

\begin{abstract}
Debris flow frequently attacks rivers on slopes of Merapi Volcano and causes fatalities and damage of infrastructures. To reduce the risk of debris flow, a warning system has been developed by Sabo Office Center. Critical line and snake line graph are applied in Merapi Volcano to monitor characteristics of rainfall in the upland river basin. However, this warning system cannot predict the arrival time and location of the debris flow occurrence. Numerical simulation seems to be a good tool to improve its performance. This research proposed an idea to combine rainfall-based warning system with the numerical simulation model. This model used slope stability theory to identify debris flow initiation. Results of this research showed that fluctuation of rainfall intensity reflects changes of debris flow initiation area. The more severe rainfall intensity, the larger volume of surface flow, and thus the greater debris flow initiation takes place. When the rainfall monitoring is combined with the debris flow simulation results, there is a tendency of the enlargement of the debris flow area to follow the growth of the hourly rainfall.
\end{abstract}

Keywords: Debris flow, critical line, rainfall-based warning system

\section{Introduction}

Debris flow is the most frequent disaster taking place in some rivers in Merapi Volcano area, Indonesia. It damages public infrastructures, destroyed bridges, houses, and causes fatalities. One of the worst damaged occurred in 2010 associating the enormous eruption. It took place in Jumoyo Village, Magelang City, at the downstream of Putih River. About 54 houses were drifted and buried by debris flow under 2-4 m of sediment, 41 houses damaged, and 1005 people evacuated [1]. Approximately 10 million $\mathrm{m}^{3}$ of volcanic materials were ejected from the crater as the product of Merapi eruption in 2010 [2]. Those materials were deposited on river channel and easily eroded by surface runoff. Progressive erosion widens the gully and further initiates debris flow [3]. It does not only threat just after eruption, but may also continue a few years after eruption, thus a warning system of debris flow should be applied.

Sabo Office Center which is in charge of developing debris flow information in Merapi applies rainfall-based warning system to reduce the risk of debris flow. Critical line and snake line graph are applied in this system to monitor characteristics of rainfall in the upland river basin. Sabo Office applies critical line judgment graph according to MLIT Japan. Critical line distinguishes rainfall triggering debris flow (causing rainfall) and rainfall that cannot trigger debris flow (non-causing rainfall) [4]. Working Rainfall, $R W$ is defined as cumulative rainfall influenced by antecedent working rainfall $(R W A)$. Term of 'cumulative rainfall' was defined by MLIT as a continuous rainfall that is isolated by the absence of rain for 24 hours or more, both before and after occurrence. $R W A$ represents accumulated rainfall during 
several days before disaster occurs. Debris flow monitoring is manifested in the forms of snake line graph. It shows current status of rainfall as the changes in cumulative rainfall and rainfall intensity indices with time. Snake line may traverse the critical line if rainfall continues for long time or an intense rainfall occurs during short period. If this condition happens, debris flow warning is issued to the people.

Unfortunately, this system cannot predict time and location of debris flow initiation. To provide reliable information, a warning system of debris flow should not only support by adequate technologies, but also good analysis in detecting location and arrival time of debris flow so that it can give adequate time to the people to evacuate. A numerical simulation integrated with rainfall monitoring is deemed as one of the solutions to improve the reliability of debris flow warning system. With the help of GIS-based (Geographic Information System) distributed rainfall runoff model, debris flow prone areas can be identified as well. Thus, this research proposed the idea to combine rainfallbased warning system with the theoretical analysis of debris flow initiation. Takahashi [5] developed a theory of sediment stability to predict debris flow. It can be used for identifying the debris flow prone area. This model can give the spatial and temporal information on lahar initiation can be obtained.

\section{Application of Distributed Rainfall Runoff Model}

Miyata et al. [6] developed a distributed hydrological model based on kinematic wave model. The model developed by Miyata et al. [6] deals with hillslopes and channels separately. In a slope-runoff module, transformation process from rainfall to surface flow, is calculated with two-dimensional kinematic wave model, while channel module applies one-dimensional kinematic wave model. Network of river channel is created through DEM (Digital Elevation Model) data processing applying Geographic Information System. Surface flow generated by rainfall over hillslope grids drains into the channel. Illustration of the flow components through soil layers can be seen in Fig. 1.

By considering flow at rectangular plane with cross-sectional area, surface flow at unit width, and inflow from excess rainfall intensity $r$, surface flow depth can be calculated using the following equation.

$$
\frac{\partial h_{O F}}{\partial t}+\frac{\partial q_{O F}}{\partial x}=r(x, t)-f_{c}
$$

where $A$ is cross-sectional area $\left(\mathrm{m}^{2}\right), B$ is channel width $(\mathrm{m}), q_{O F}$ is surface flow discharge at unit width $\left(\mathrm{m}^{2} / \mathrm{s}\right), \mathrm{h}_{O F}$ is surface flow depth $(\mathrm{m})$, and $f_{c}$ is maximum infiltration capacity (mm/hour). $x$ and $t$ denote spatial (m) and temporal resolution (s), respectively.

Based on the kinematic wave concept that equating bed slope with friction gradient, surface flow can be estimated by using Manning equation.

$$
\begin{gathered}
u=\frac{1}{n} R^{2 / 3} I^{1 / 2} \\
q_{O F}=\frac{\sqrt{I}}{n} h_{O F}^{5 / 3}
\end{gathered}
$$

where $n$ is Manning roughness coefficient, $R$ is hydraulics radius, and $I$ is energy gradient. Subsurface lateral flow in $A$ layer can be calculated as follows:

$$
\begin{gathered}
\frac{\partial h_{A}}{\partial t}+\frac{\partial q_{A}}{\partial x}=q_{i n_{-} A}-q_{i n_{-} B} \\
q_{A}=I_{A} K_{A} h_{A}
\end{gathered}
$$

where $q_{A}$ and $q_{B}$ are the saturated lateral flow in subsurface $A$ layer into adjacent grid and in $B$ layer into adjacent grid, $q_{i n_{-} A}$ and $q_{i n_{-} B}$ are infiltration from ground surface to $A$ layer, and from $A$ layer to $B, K_{A}$ is mean coefficient of permeability in layer $A$ and $B, I_{A}$ represents hydraulic gradient of flow at $A$ layer. Subsurface lateral flow in $B$ layer were obtained using the same continuum and momentum.

To calculate the flow discharge $q_{C H}$ and water level $h_{C H}$ in the channel, one-dimensional analysis of unsteady flow using the following equations are applied.

$$
\begin{aligned}
& \frac{\partial h_{C H}}{\partial t}+\frac{\partial q_{C H}}{\partial x}=q_{L} \\
& q_{C H}=\frac{\sqrt{S_{C H}}}{n} h_{C H}^{5 / 3}
\end{aligned}
$$


where $q_{L}$ denotes lateral flow obtained from the hill slope simulation including subsurface flow and surface flow.

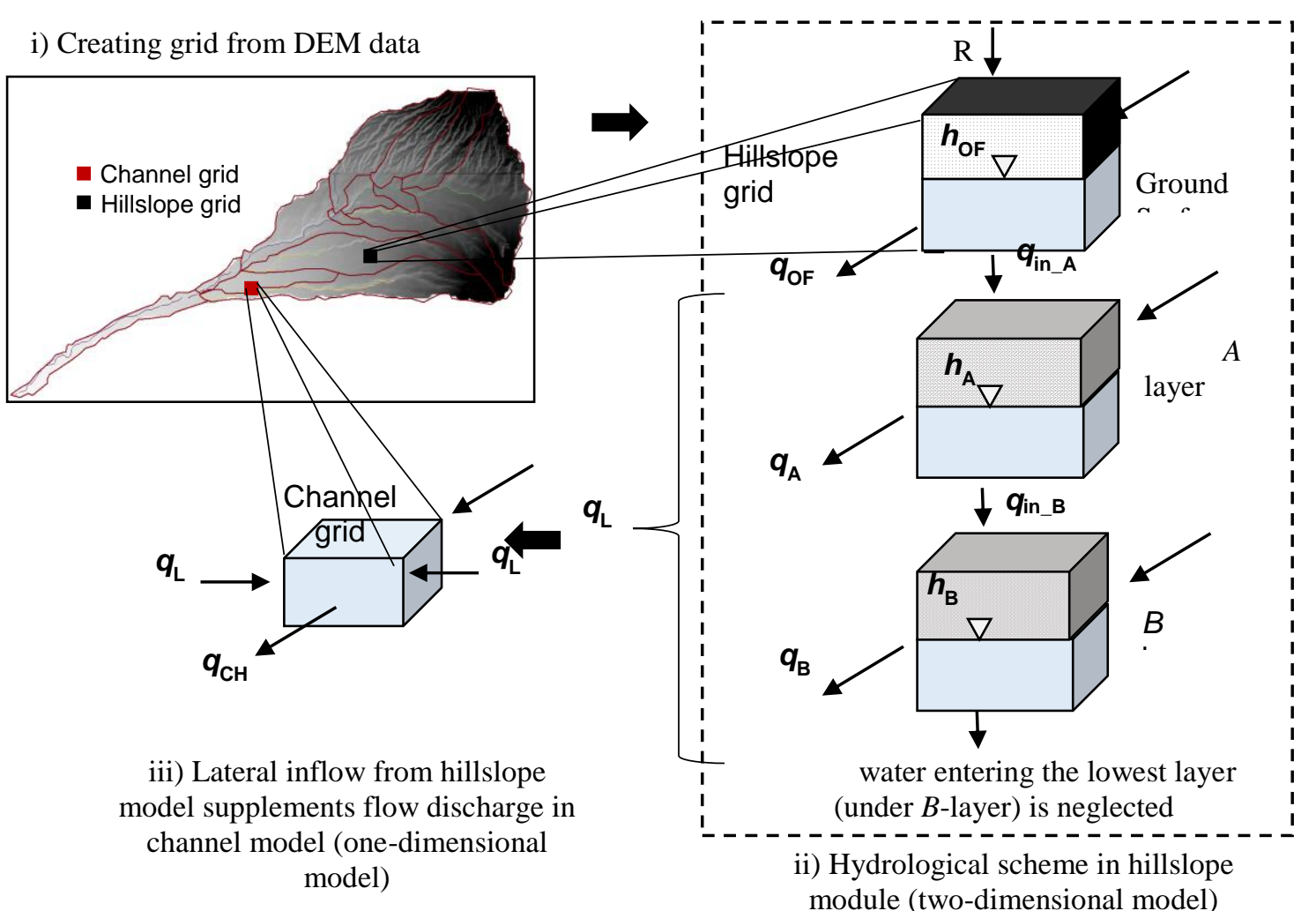

Fig. 1 - Scheme of the rainfall-runoff model [7]

\section{Theory of the Initiation of Debris Flow}

Takahashi [5] described the initiation of debris flow in term of slope stability analysis based on limit equilibrium. Slope stability depends on the driving shear stress caused by the weight, $\tau$ along sliding block and the resisting shear stress $\tau_{\mathrm{r}}$. If $a$ is assumed as the depth coordinate corresponding to the channel bed, the driving shear stress is yielded by combination between the hydrostatic pressure at the height $a+h$ and weight of both sediment mixture perpendicular to the surface. Distribution of the driving shear stress will be as follows:

$$
\begin{gathered}
\tau=\left(\rho(h+a)+\left(\rho_{s}-\rho\right) a C_{*}\right) g \sin \theta \\
\tau_{r}=\left(\rho_{s}-\rho\right) C_{*} a \cos \theta \tan \varphi
\end{gathered}
$$

When the soil layer is in saturated condition and surface runoff exists, sediment bed tends to be unstable if it satisfies the following equation.

$$
\tan \theta=\frac{\left(\rho_{s}-\rho\right) C_{*}}{\left(\rho_{s}-\rho\right) C_{*}+\rho\left(1+h / a_{c}\right)} \tan \varphi
$$

In the form of critical relative submergence, Eq. (11) is expressed as follows:

$$
\frac{h}{a_{c}}=\Delta C_{*}\left(\frac{\tan \varphi}{\tan \theta}-1\right)-1
$$

where $a_{c}$ is intersection between resisting shear stress line with driving shear stress line.

Sometimes, it is difficult to determine which one is debris flow and which one is normal stream flow. Takahashi [4] distinguished debris flow type based on the sediment concentration, C. The sediment-water mixture behaves like debris flow if the sediment concentration exceeds 0.2. Sediment concentration less than 0.2 is defined as immature debris flow in which the collision stress dominates only in the lower layer of sediment-water mixture flow. 


\section{Methodology}

\subsection{Debris Flow in Putih River Basin}

Investigation of the debris flow initiation was carried out in Putih River Basin. It was located in the Southwest of Merapi Volcano. During 2010-2012, mostly debris flow events took place in Putih River Basin [8], [9]. Furthermore, it is also the most exploited quarries in Merapi. About 2600 people excavate deposited materials per day and they should face the risk of debris flow every day. Therefore, development of the debris flow risk and mitigation in Putih River is crucial. Based on the aforementioned reasons, this research was focused on Putih River (Fig. 2). It used a debris flow event in Putih River that occurs in 25 December 2012 (Fig. 3). In that event, debris flow damaged one temporary bridge in Seloboro Village, Magelang Regency. Prior to that debris flow event, a heavy rainfall occurred. According to rainfall records of a monitoring station at Maron hill (Maron station), rainfall occurred from 14.30 until 16.00 (GMT+7) or 90 minutes. The peak of rainfall intensity was about $84 \mathrm{~mm} /$ hour as shown in Fig. 5. The increase of water level in developing debris flow were observed from water level station. At 14.11, water level in PU-D4 dam increased up to 1 $\mathrm{m}$ height and $60 \mathrm{~m}$ width. Peak of flow discharge in PU-D4 dam was reached within 10 minutes. This information was attained from community of radio communication in Merapi. It was proved by water level monitoring station installed in PU-C11 Station which was located $4 \mathrm{~km}$ from PUD4 or $13 \mathrm{~km}$ from the crater. At 14.34, peak of flow discharge reached PUC11 station with $0.5 \mathrm{~m}$ height (Fig. 4). Recent condition of river channel at PU-C11 and PU-D5 dam are shown in Fig. 4. Sample of the sediment was taken at PU-C11 and PU-D5 Dam. The physical characteristics of sediment is shown in Table 1.

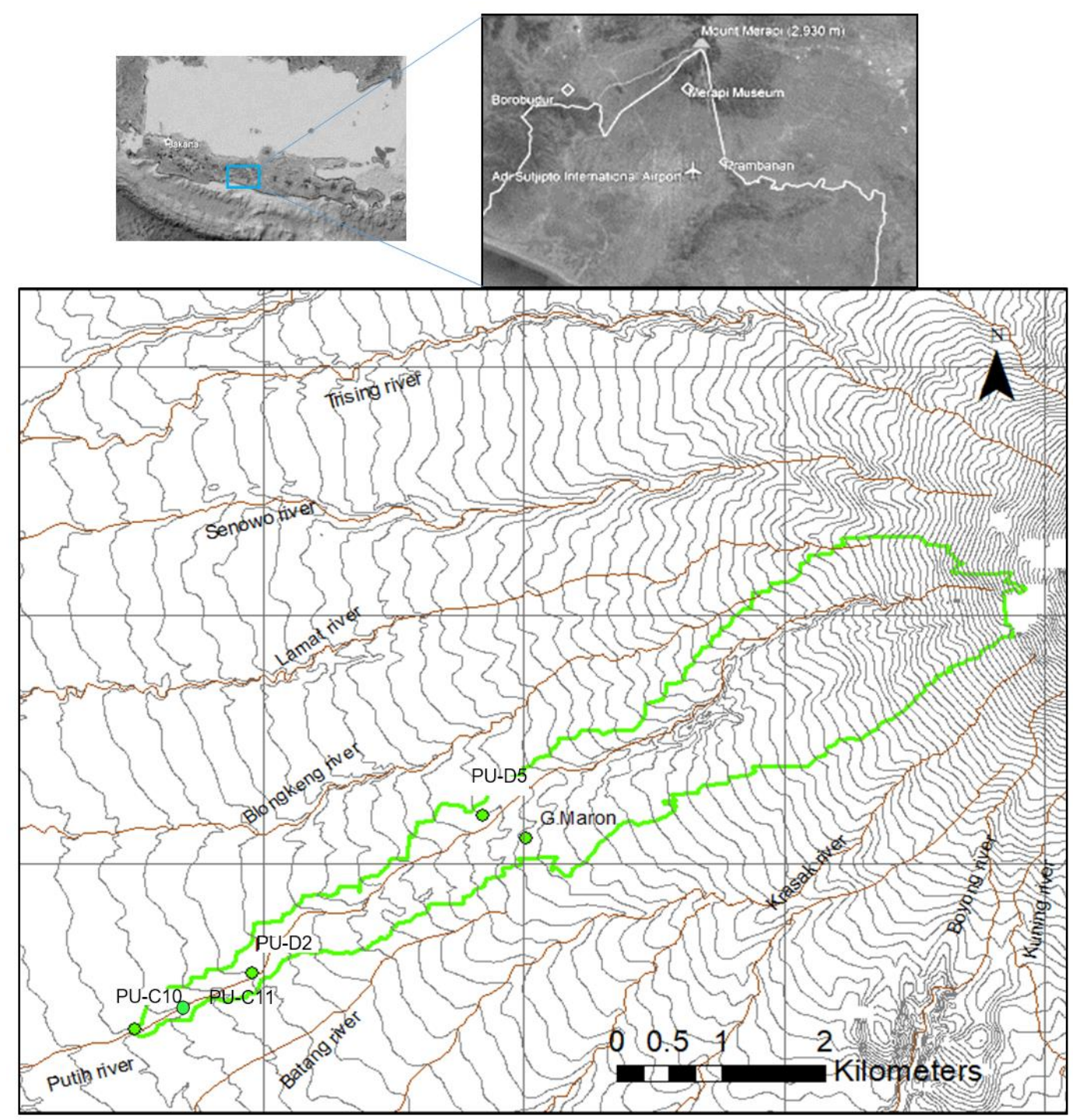

Fig. 2 - Research location

Table 1 - Physical characteristics of sediment 


\begin{tabular}{ll}
\hline Parameter & Sample from PUD5 \\
\hline Specific gravity & $2.70-2.86$ \\
Water content & 0.05 \\
Mean void ratio & 0.61 \\
Mean porosity & $37.71 \%$ \\
Internal friction & $40.82^{\circ}-44.44^{\circ}$ \\
Cohesion & $0.05 \mathrm{~kg} / \mathrm{cm}^{2}$ \\
Dry density & $1.79-2.07 \mathrm{ton} / \mathrm{m}^{3}$ \\
Bulk density & $1.73-1.91 \mathrm{ton} / \mathrm{m}^{3}$ \\
\hline
\end{tabular}

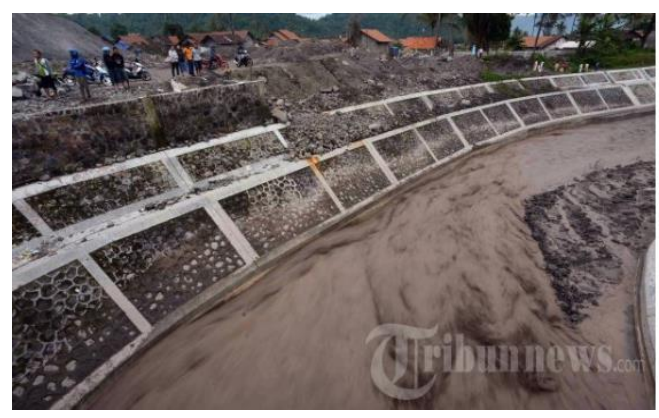

Fig. 3 - Debris flow in Putih River, Jumoyo Village, Magelang Regency in December 25th 2012 [10]

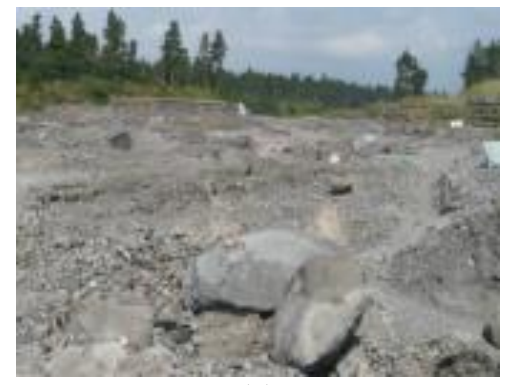

(a)

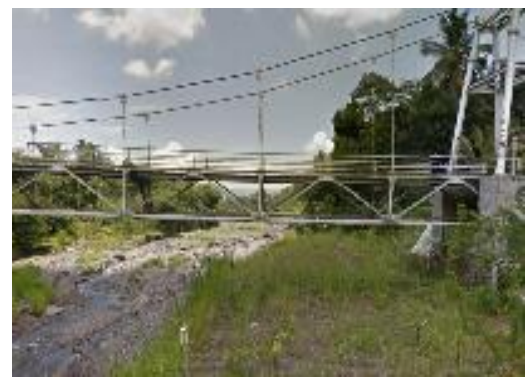

(a)

Fig. 4 - Location of the Sampling Test, (a) PU-D5 Dam, (b) PU-C11 Dam

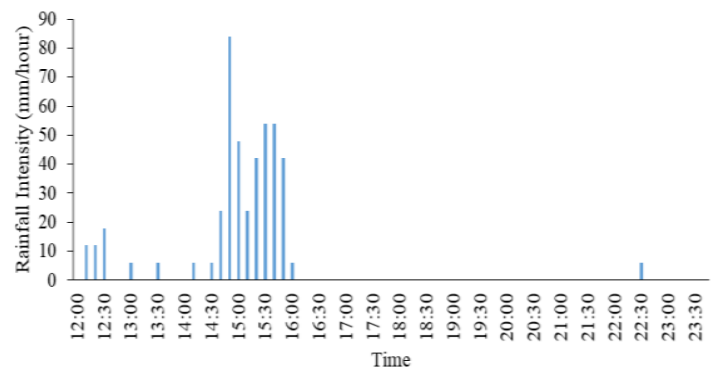

(a)

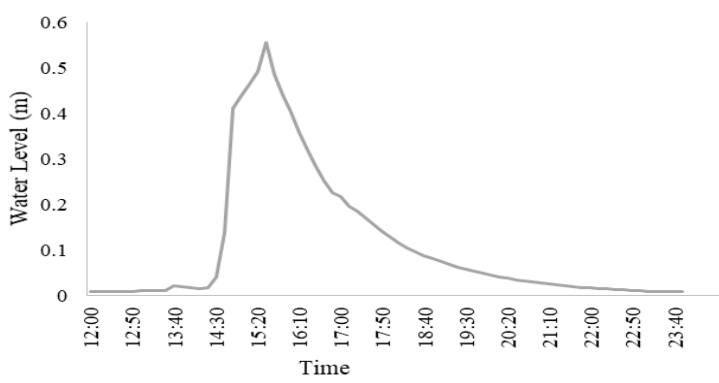

(b)

Fig. 5 - Data of (a) rainfall (Maron Station); (b) water level (PU-C11 Station) in 25 December 2012

\subsection{Conditions of the Numerical Simulation}

Simulation domain of Putih River consists of 90,300 of grids number with $10 \mathrm{~m}$ x $10 \mathrm{~m}$ resolution. The outlet point of basin located in PU-C10 dam. Thickness of $A$-layer was based on the thickness of root zone, while thickness of $B$ layer was based on the average thickness of debris flow deposit in Putih River which was approximately $1.8 \mathrm{~m}$ [8]. Since maximum infiltration capacity and $n$ Manning roughness could be diverse in a basin, those parameter values were obtained by a calibration process. Values of maximum infiltration capacity and $n$ Manning coefficient were adjusted to 
comply with the observed flow discharge. Despite of using ground rainfall station, calibration were conducted by using rainfall data captured by X-Band Multiphase (XMP) Radar for giving more detail information on the spatial distribution of rainfall. XMP Radar captures rainfall in a 150 by 150 sq. m area every 2 minutes. Fig. 7 showed visualization of XMP radar and observed flow discharge in PU-C11 station on 5 January 2017. Both XMP radar and PU-C11 Station show the peak rainfall around 14.00 WIB. The intense rainfall was associated with an increase in water level. It can be seen in Fig. 6. Abrupt changes of elevation above dam crest were recorded at 15.00 WIB. Some ascending points that stand alone or do not show discontinuous line are deemed as noises.

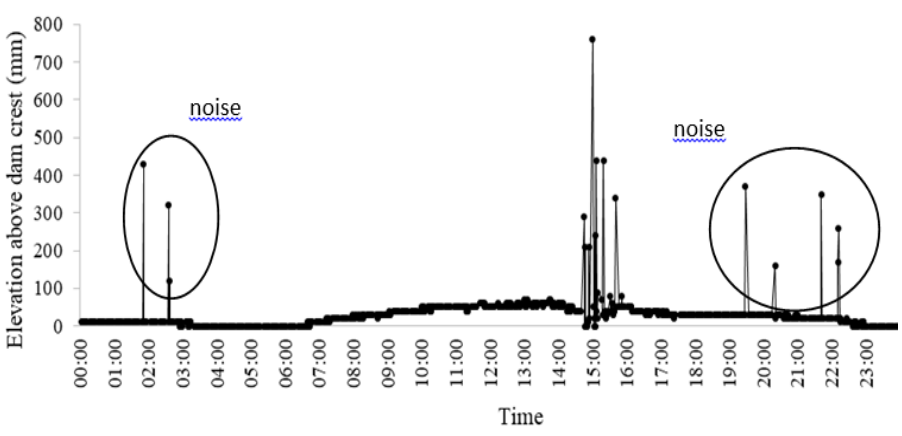

Fig. 6 - Water level monitoring in PU-C11 dam on 5 January 2017

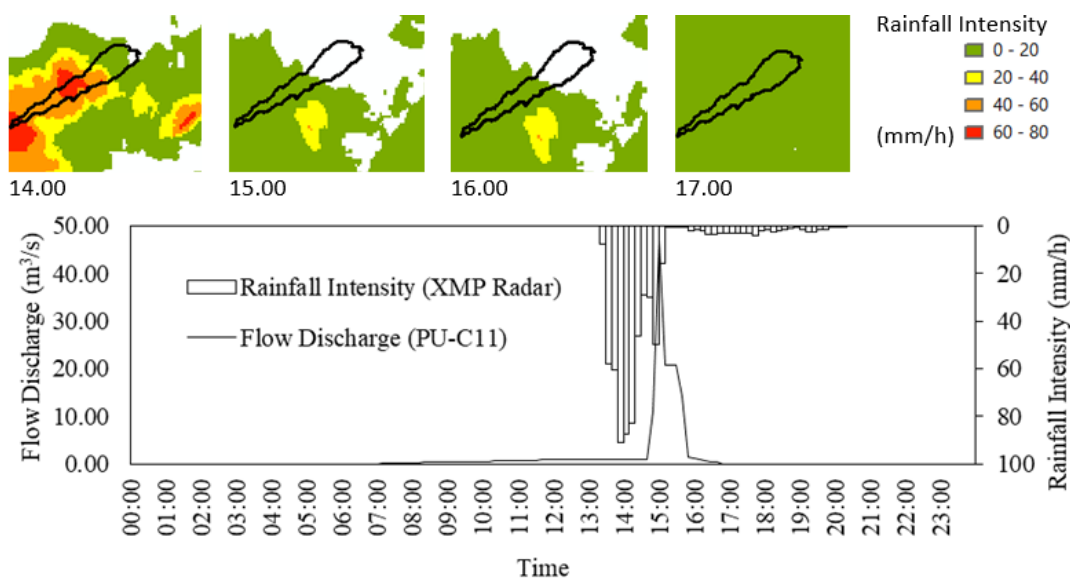

Fig. 7 - Flow discharge monitoring in PU-C11 dam (below) and XMP radar (above) on 5 January 2017

\subsection{Identification of Debris Flow Initiation Area}

Input parameter value obtained from verification results was applied to investigate initiation area of debris flow events on cell basis 25 December 2012. Initiation area of debris flow is identified in a cell by Eq. (14). Flow depth in a cell as the product of slope runoff simulation was used to calculate unstable bed thickness which is likely to move. According to Takahashi [5], sediment concentration in which the flow behaves debris flow was 0.2. This limit was applied to identify debris flow initiation area. Depth of the unstable bed layer, $a_{c}$ was calculated using Eq. (14), while sediment concentration was obtained from the ratio of solid particle volume and total volume. Area of the initiation of debris flow, $A_{\text {in }}$ was identified based on sediment concentration. Based on definition, when $C$ exceeds 0.2 , debris flow will occur.

\section{Results and Discussions}

\subsection{Calibration of the Model}

Soil infiltration rate and Manning roughness coefficient affect the amount of surface flow generated by rainfall. Higher infiltration rate enables more surface flow to infiltrate into the soil, thus the surface flow decreases. Roughness coefficient gives effect on the flow velocity. The higher roughness coefficient causes lower flow velocity, it gives more time to infiltrate, thus the surface flow decreases [11], [12]. Manning roughness coefficient were calibrated. After conducting simulations with variation of infiltration capacity and $\mathrm{n}$ Manning coefficient, one simulation was in conformity with the observed data (Fig. 8). It applied $45 \mathrm{~mm} / \mathrm{h}$ of infiltration capacity and 0.13 of $n_{\text {Manning.. These }}$ parameter values were applied for investigating debris flow case in 25 December 2012. 


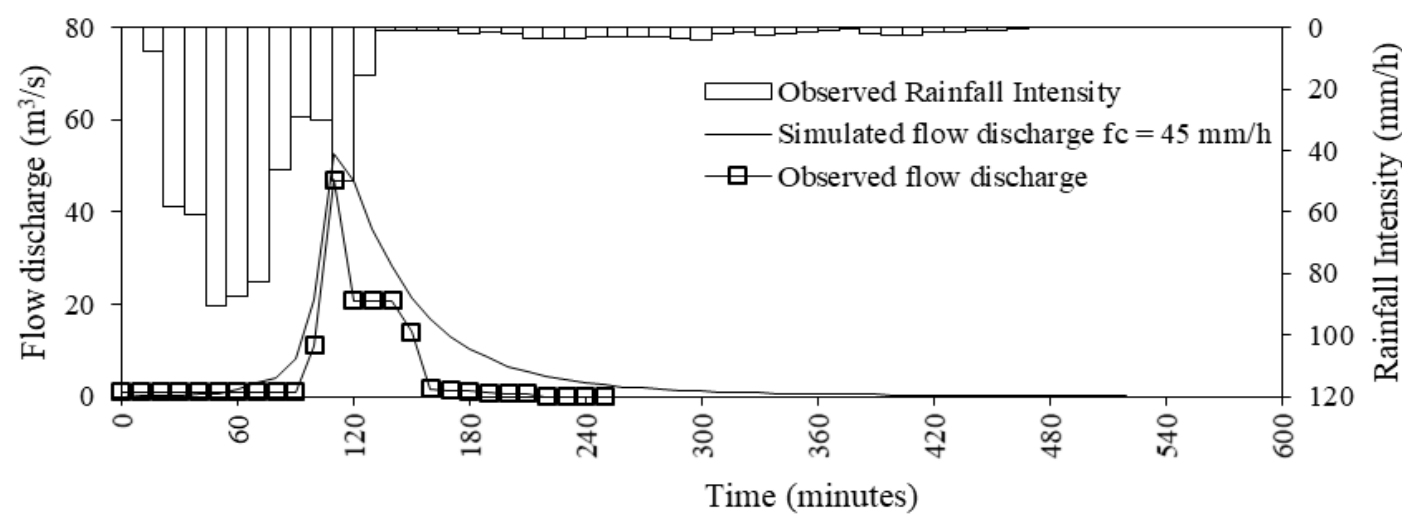

Fig. 8 - Comparison between observed data and simulation results

\subsection{Spatial Information on Debris Flow}

Initiation of debris flow caused by gully bed erosion is predominantly affected by surface flow depth [5]. Spatial distribution of surface flow depth for the case of debris flow event on 25 December 2012 are shown in Fig. 9. In this simulation case, rainfall was assumed evenly distributed over whole catchment. Simulation was started at the beginning of the rainfall. Rainfall raised to the peak when $t=30$ minutes and stopped at $t=100$ minutes. Simulation results show that surface flow appeared 60 minutes from the beginning of the rainfall with less than $0.02 \mathrm{~m}$ depth. Surface flow at the gullies and streams were found in the range of $0.02-0.1 \mathrm{~m}$ depth. At $\mathrm{t}=90$ minutes, the surface flow depth increased. It was $0.02 \mathrm{~m}$ in average and $3.4 \%$ of the total area was over $0.1 \mathrm{~m}$ depth. When rainfall decreased, the total amount of surface flow reduced more than $50 \%$ compared to the results at 120 minutes. It indicated that smaller rainfall amount, the less contribution of surface flow depth to the channel module [13]. Fig. 9 also showed the surface runoff flew downward and accumulated to the low areas. Surface runoff on the hillslope entered the gullies and flew down to the streams. At $t=150$ minutes, surface runoff at the hillslope were decreased significantly, but on the contrary, surface flow at the streams reached the highest depth. It was depicted in Fig. 10. Peak of the flow discharge at $t=150$ minutes was about $45 \mathrm{~m}^{3} / \mathrm{s}$. The recent research only investigated the initiation of debris flow, so that the debris flow might not be fully developed.
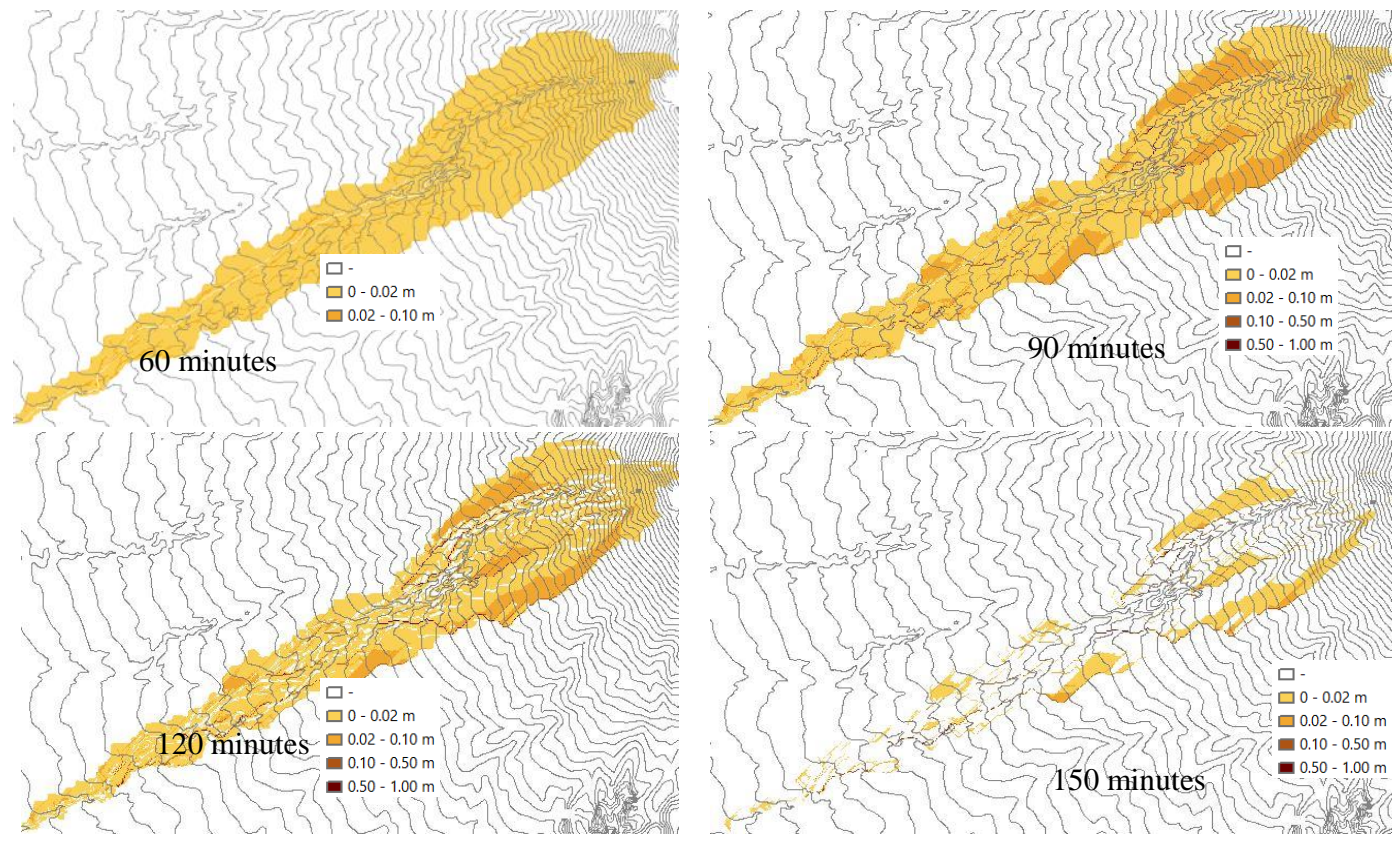

Fig. 9 - Distribution of runoff depth based on the simulation results for debris flow event at 25 December 2012 [7]

Distribution of the surface flow depth was used for identifying grids in which debris flow initiated. At $t=60$ minutes, debris flow initiation area was about $53 \%$ of the total area, then increased at $t=90$ minutes. Decrease of the surface flow depth was associated with the decrease of debris flow initiation area. At $t=150$ minutes, debris flow initiation area fell into $8 \%$ of the total area and it was nearly zero about 2 hours after peak of the rainfall. Percentage of debris flow initiation area was obtained by summing up all grids that enable debris flow without considering they are in 
a group or number of single grids. However, this assumption needs to have much concern, since contribution of group of grid may be different to number of single grids even if they have the same amount.

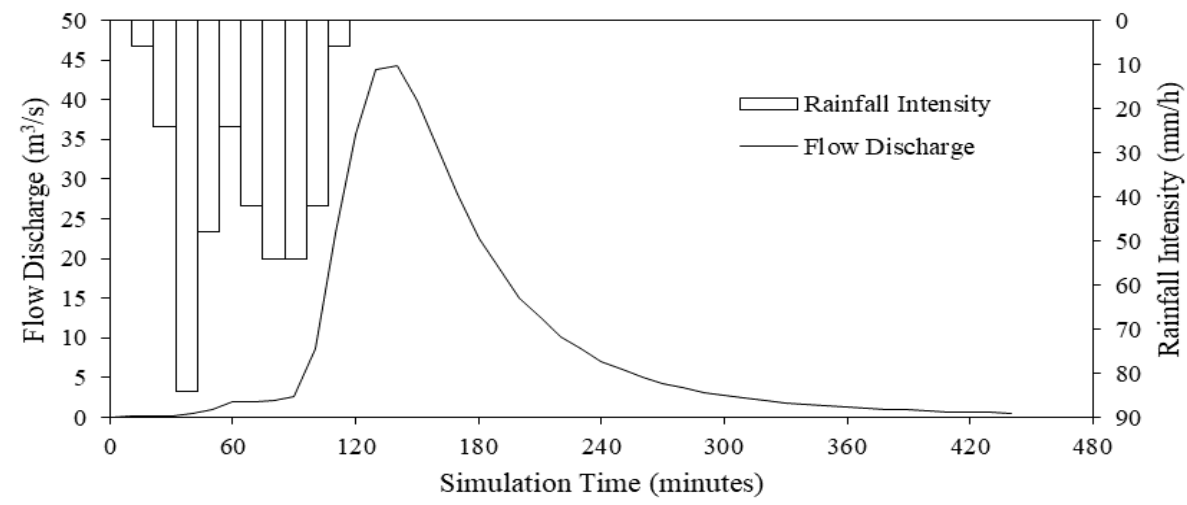

Fig. 10 - Flow discharge at PU-C11 based on the simulation results [7]
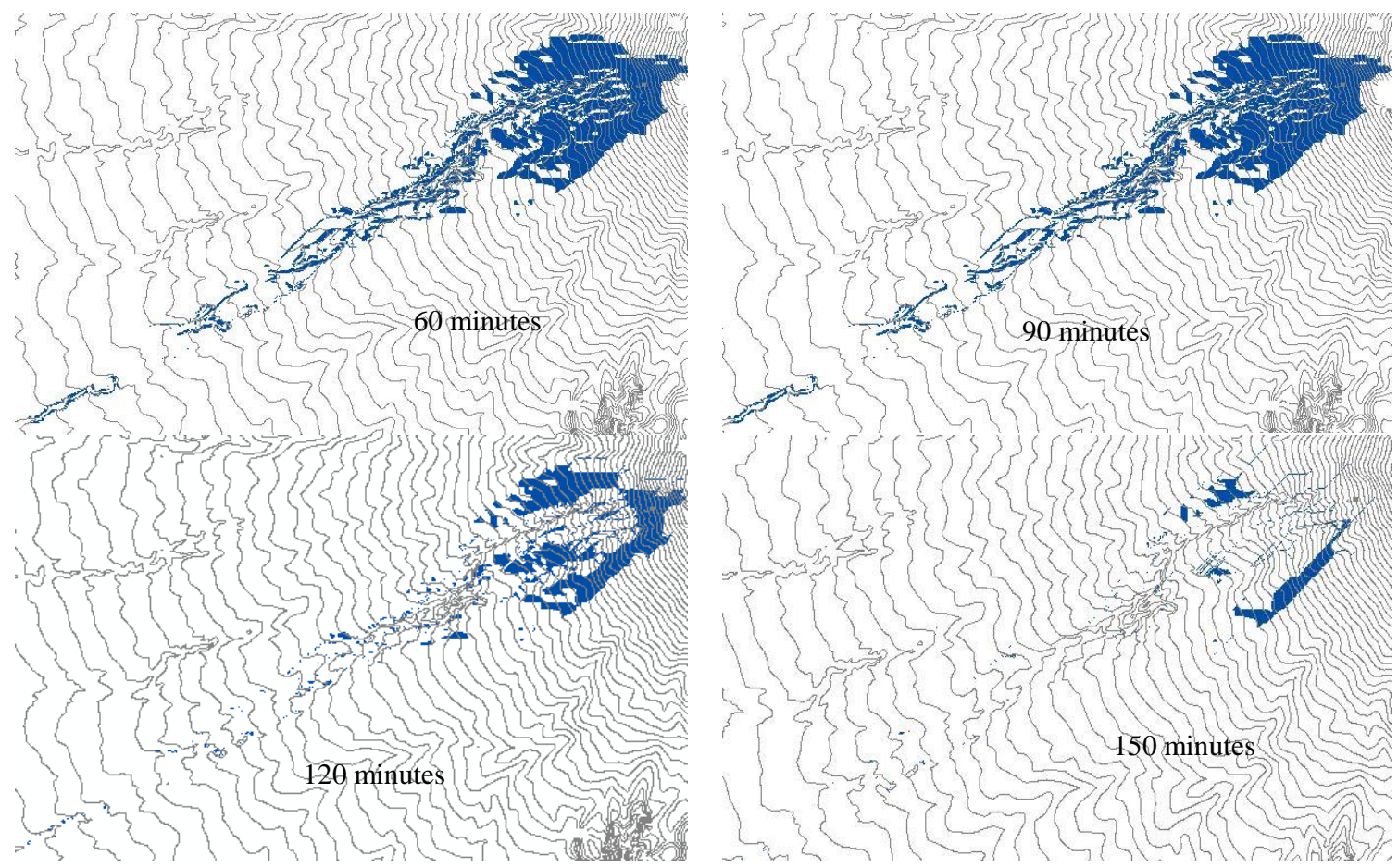

Fig. 11 - Initiation area of debris flow (coloured in blue) based on the simulation results for debris flow event at 25 December 2012 [7]

\subsection{Snake Line Characteristics of Debris Flow}

Changes of debris flow initiation area for different rainfall intensity are shown in Fig. 12. Fluctuation of rainfall intensity reflects changes of debris flow initiation area. When the rainfall intensity was small, no debris flow was detected, yet when the high intensity rainfall occurs, it can abruptly induce significant increase of debris flow initiation area within only less than 20 minutes. It implies that the more severe rainfall, the greater amount of grids in which debris flow initiates. Snake line combined with the debris flow simulation results was shown in Fig.16. Connection between snake line movement and risk of debris flow can be examined. $A_{\text {in-t }}$ represents debris flow initiation area at time $t$ from the beginning of the simulation. Fig. 13 implies that the largest debris flow area occurred 60 minutes after simulation $\left(A_{\text {in-60 }}\right)$ coinciding with the recorded debris flows. The data of occurrence time of the debris flow events were obtained from the news, interview, and Sabo Research Center data. Debris flow occurrence that was plotted on the graph of hourly rainfall is called as causing rainfall. Fig. 13 shows rainfall causing debris flow were predicted before the peak of hourly rainfall. Noted that the simulation only predicts the initiation of debris flow. Occurrence time of the historical debris flow was based on the arrival time of debris flow to the downstream. It might be the reason why the 
simulation results seem to differ from the historical data. However, it seems that percentage of debris flow initiation area triggering debris flow to the downstream should be also justified to know the arrival time of debris flow.

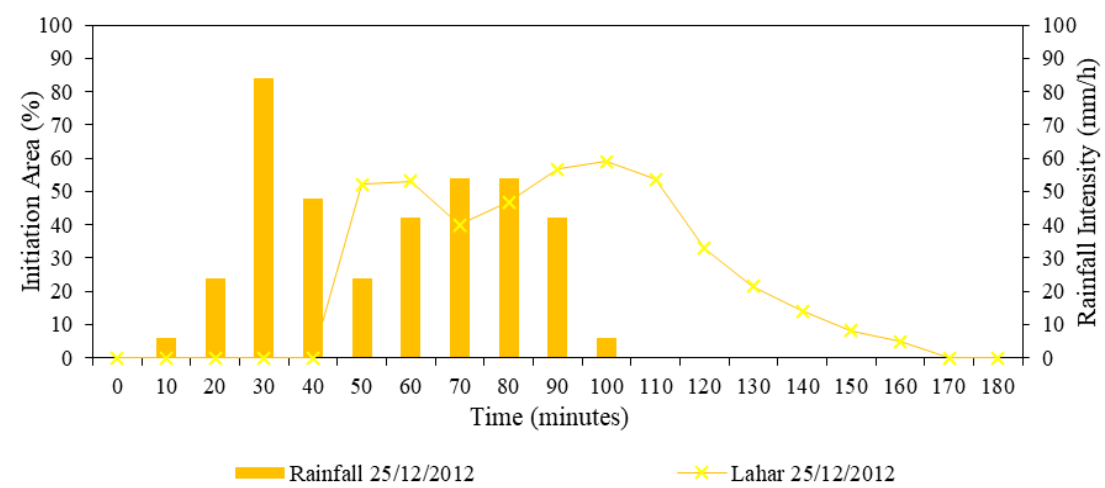

Fig. 12 - Debris flow initiation area and rainfall intensity for case of debris flow 25 December 2012

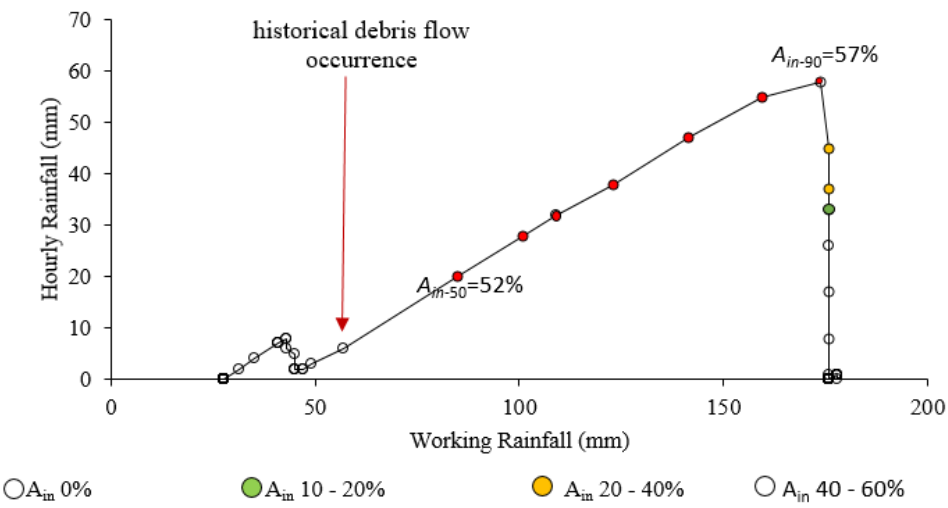

Fig. 13 - Snake line characteristics of debris flow event in 25 December 2012

\section{Conclusions}

The simulation results were able to indicate a spatial distribution of debris flow initiation area caused by the rainfall. Fluctuation of rainfall intensity causes changes of debris flow initiation area. The more severe rainfall intensity, the larger volume of surface flow, and thus the greater debris flow initiation takes place. When the knowledge of the rainfall monitoring data is combined with that of the debris flow simulation results, connection between progressing rainfall and risk of debris flow can be seen. It indicates the enlargement of the debris flow area to follow the growth of the hourly rainfall. Debris flow simulation results coincide with the occurrence time of the historical debris flow. Some results show that debris flow initiates before the peak of hourly rainfall were achieved. Simulation of debris flow case 25 December 2012 shows that before the peak of hourly rainfall, debris flow initiation area decreases. It seems that fluctuation of debris flow initiation area much depends on short duration rainfall which is less than 60 minutes rainfall. Therefore, a spatially-distributed rainfall with short duration time is required to provide important information of the dynamic of rainfall intensity during heavy rainfall condition.

\section{Acknowledgement}

The authors wish to thank Sabo Office Center and Hydraulic Laboratory of Department of Civil and Environmental Engineering for providing precious data. The authors also gratefully acknowledge Mr. Shusuke Miyata for valuable discussions and the permission to use his model to conduct study on debris flow warning in Merapi Volcano.

\section{References}


[1] Surjono S. S. \& Yufianto A. (2011). Geo-disaster laharic flow along Putih River, Central Jawa, Indonesia. Journal of Applied. Geology, 3(2), 103-110

[2] National Disaster Management Agency (2011). BNPB Report. http://www.bnpb.go.id/website/asp/ berita_list.asp?id=434

[3] Hu W., Xu Q., van Asch T.W., Zhu X. \& Xu Q. Q. (2014). Flume tests to study the initiation of huge debris flows after the Wenchuan earthquake in SW China. Engineering geology, 182, 121-129

[4] Ministry of Land, Infrastructure, and Transport (2004). Guidelines for Construction Technology Transfer, Development of Warning and Evacuation System against Sediment Disaster in Developing Countries. Infrastructure Development Institute, Japan

[5] Takahashi T. (1991). Debris Flow, in Monograph of IAHR. Balkema, pp. 1-165

[6] Miyata S., Fujita M., Teratani T. \& Tsujimoto H. (2014). Flash flood due to local and intensive rainfall in an alpine catchment. Proceedings of the INTERPRAEVENT, pp. 256-263

[7] Hairani A. (2020). Development of Threshold Criteria for Rainfall-Triggered Lahar. Dissertation Report, Universitas Gadjah Mada, Yogyakarta

[8] De Bélizal E., Lavigne F., Hadmoko D. S., Degeai J. P., Dipayana G. A., Mutaqin, B. W., Marfai M. A., Coquet M., Le Mauff B., Robin A. K. \& Vidal C. (2013). Rain-triggered lahars following the 2010 eruption of Merapi volcano, Indonesia: A major risk. Journal of Volcanology and Geothermal Research, 1(261), 330-347

[9] Legono D., Jayadi R., Rahardjo A. P. \& Hairani A. (2016). Snake line characteristic triggering lahar flow occurrence at Mt. Merapi area. Congress of IAHR-APD 2016, Colombo

[10] Tribunnews (2012). Lahar Merapi. http://www.tribunnews.com/images/regional/view/ 318251/banjir-laharhujanmerapi

[11] Widowati A. P. A. (2017). Hydraulic and hydrologic modeling of steep channel of Putih River, Magelang District, Central Java Province, Indonesia. Journal of the Civil Engineering 3(3),125-134

[12] Duhita A. D. P., Rahardjo A. P., Hairani A. (2021). The effect of slope on the infiltration capacity and erosion of Mount Merapi slope materials. Journal of the Civil Engineering 7(1), 71-84

[13] Hairani A., Rahardjo A. P., Legono D., Istiarto \& Miyata S. (2018). Spatially distributed evaluation of initiation of mass erosion. Congress of IAHR-APD 2018, Yogyakarta 